\title{
The Relationship Analysis Between Knowledge \& Skills, Organizational Drivers, and Perceived Success in Implementation of Agile Project Management: Case Study of PT XYZ
}

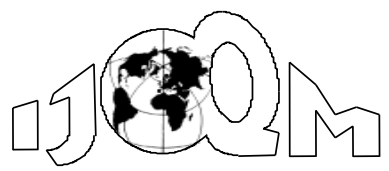

DOI: $10.46970 / 2021.27 .2 .2$

Volume 27, Number 2

June 2021, pp. 111-126
Mohammad Hamsal

Mohammad Ichsan

Annisa Rizky Utomo

Aulia Ayu Fahira

Rima Emeralda Wetik

Bina Nusantara University

(d3919@binus.ac.id)

Since information technology changes faster, demanding companies must react quickly and appropriately to the projects carried out. This condition requires an approach to keep the company's projects in a safe state even in an unstable business environment. This study discusses an agile that offers solutions to make the project implementation process more responsive to changes in an unstable project environment. This study was conducted to determine the relationship between knowledge and skills with perceived success in implementing agile project management in companies and how organizational drivers mediate these relationships. Quantitative empirical methods were used as a method for answering the results. The results of this study showed that only the variable knowledge and skills had a significant influence on perceived success, while the variable of organizational factors did not. The results of this study provide an understanding of the implementation of agile project management in companies.

Keywords: Agile, Knowledge, Skills, Organizational Drivers, Perceived Success

\section{Introduction}

In the age of the industrial 4.0 revolution, Indonesia has shown a tremendous growth in information technology sector [1]. These rapid changes in information technology, especially in Indonesia, require quick and appropriate responses to ongoing projects at any time and in any situation.

This condition requires an approach so that the company remains in a safe condition even in a changing and unstable business environment. Regarding these problems, the agile approach (Agile Methodology) offers a solution to minimize project complexity in unstable business conditions.

PT XYZ is an information technology company with business activities as a provider of Internet and cable TV services in Indonesia. Due to the current business conditions, PT XYZ always requires a fast and precise response to the projects they are working on. The current terms and conditions listed above encourage PT XYZ to implement agile project management. 
Agile project management approach is applied at PT XYZ in running every project from all divisions. At the time of this study, the researcher did not find any secondary data. Therefore, the researcher took the initiative to conduct a preliminary survey with 37 respondents. As a result, the effectiveness of implementing Agile Project Management at PT XYZ is still relatively low, because Agile Project Management has not been used intensively, although the response from the company itself to implement Agile Project Management is quite high.

Therefore, this paper will examine the following research questions (RQ)

1. How is relationship between knowledge and skills with perceived success in APM implementation in PT XYZ?

2. How organizational drivers influence the relationship between knowledge and skills with perceived success in APM implementation in PT. XYZ?

\section{Theoretical Review}

\subsection{Agile Project Management Approach}

Based on[2], Agile Project Management is an approach to a set of principles that aims to make the project management process simpler, more flexible, and continuing to get better performance (cost, time, and quality) with less management effort and a higher level of innovation and also added value for customers. Agile Project Management is a transition from the traditional project management approach where the project team plans the entire project then implements the change plan [3].

The Agile approach recognizes that change is an inevitable part of a project, so this method emphasizes project implementation in iterations and revisions in each project work cycle. The agile approach also emphasizes the need for collaboration between the project team and other stakeholders during the project development and implementation process. The goal of agile project management is to make the project implementation process responsive to changes in the project environment. Agile project management is associated with many advantages for the organization, project team, customers, and stakeholders. These advantages include reduced rework costs, faster project completion, higher customer satisfaction, individual and team development, increased performance transparency, and more creativity and innovation.

\subsection{Knowledge in Agile Project Management}

The core basic of Agile to Project Management comes from the Agile Manifesto [4]. The Agile Manifesto has shown that the greatest value from an individual comes from their individual as well as from interaction and is also inherent in some processes in the development of agile software development.

It comprises of fourscore values such as Individuals and Interaction Over Processes and Tools, Working Software over Comprehensive Documentation, Customer Collaboration over Contract Negotiation, and Responding to Change over Following a Plan. Furthermore, the Agile Manifesto is decomposed into 12 principles of Agile Manifesto. [5] and they are: 1. Prioritizing client satisfaction, 2. Accepting changing needs, 3. Releasing/releasing products regularly, 4. Collaborating, 5. Working with individuals who have high spirits, 6. Face-to-face or face-to-face communication, 7. The product can be used, 8. Having a constant speed, 9. Paying attention to technical 
excellence and having a good design, 10. Simplicity, 11. Managing you, 12. Reflection and adjustment.

\subsection{Project Management Skills}

A study from Conforto et al. reveals that project management practice is a special type of "management action" that has helped implement the project management process and is likely to use many tools and techniques [2]. The study also presents some APM practices that are useful for comparing traditional literature and agile management literature approaches to identify different actions, tools, and techniques. This journal reveals that there are 8 factors, one of which is the ability to work with team members from various disciplines.

The skills required for the successful use of APM are also important, they should hold regular meetings with other project members to confirm the planned schedule, decision making as well as transparency in the provision of information. Change management is a contractual requirement in terms of principles, rules of conduct, organizational structure, and processes established to resolve unexpected events, communicate risks using a top-down approach, or speak directly to project members. Finally, the ability to solve problems like [6].

\subsection{Organizational Drivers}

Organizational factors are one of the variables in this case study. As a continuation of the discussion on the resource-based view, the RBV emphasizes that resource organizational skills are also necessary for success in achieving outstanding performance [7]. Develop and release organizational resources such as creating a pleasant and profitable work environment and culture, investing in advanced human resource practices, strengthening marketing-related skills, and working with suppliers to improve processes, including increasing willingness to innovate and also company performance

\subsection{Perceived Project Success}

The success of implementations of agile project management can be measured using several factors. Firstly, the company perceives that the use of Agile in the project is successful if the project is completed within the allocated time from the start and not too late [8]. The perceived success of Project Management can also be seen from "The Golden Triangle" [9], which contains 3 main factors; time, cost, and quality. The perceived success of a project can be said to be successful if measured by 5 aspects including the efficiency of the project itself, the satisfaction of the project team, its impact on customers, business success, and preparing future projects for the future [10].

The project success can also be perceived from various perspectives such as stakeholder satisfaction and project efficiency has been proven to increase through Agile Project Management [11].The quality and vision of a project are also perceived as important to project success, especially when using Agile Project Management.

\section{Methodology}

This type of research is a case study and it is defined as a series of scientific activities that are carried out intensively and focus on one particular unit, whether it is 
individual, group, organization, or an event to explore further knowledge about the unit [12].The quantitative data is obtained from a measurement, where the results are in the form of numbers. The quantitative data in this study is the result of an employee survey on the implementation of Agile Project Management at PT XYZ. By using numerical or quantitative data, it is hoped that the data obtained can be measured accurately and their validity verified. Therefore, the approach proposed in this study is quantitative. Quantitative research has a structured data collection process where data is collected objectively and systematically [13], then the numerical data analysis was carried out by statistical methods, and SPSS was used in this study as an analytical tool.

\subsection{Data Collection}

The data collected in this study came from an online survey conducted using Google forms. The survey was conducted twice, with the first survey being conducted before the study to find out the phenomenon in the company on the subject, then the second survey was conducted to obtain data to be tested in the study.

Before being formally distributed to participants, validation was carried out by experts and pilot surveys. The questionnaire is a closed statement questionnaire, where each statement has been given a choice of answer choices so that respondents can answer directly. Each statement in the questionnaire then explains the answers to the variables in this study; Knowledge \& Skills, Organizational Drivers, and Perceived Success in the implementation of Agile Project Management in the company.

The Likert scale has been chosen to obtain interval data in the questionnaire as a research instrument. It was designed to measure the perception of attitudes and behavior of respondents in certain circumstances following the research variables [14]. The questionnaire uses the 6-point Likert scale as follows; 1 = "very dissatisfied"; 2 = "not satisfied"; 3 = "not satisfied"; 4 = "quite satisfied"; 5 = "satisfied"; 6 = "very satisfied"). An even number Likert scale has been proposed, as it will force respondents to commit to a certain position without an intermediate choice [15]. A purposive sampling technique has been proposed as not all employees are eligible to participate in the survey.

Purposive sampling is a non-probability sampling technique where the chosen objects from the population do not have the same opportunity to be included in the sample [16]. The expected respondent participating in the survey shall have the following criteria as; a minimum of supervisor level, have been participating in a project in the company, having a project management certification - agile certification is preferred but not mandatory. The questionnaire will be distributed to several divisions at PT XYZ.

\subsection{Analysis}

First of all, a descriptive statistical analysis is used to analyze data that has been collected without the intention to make conclusions by generalizing them [17]. The variables in this study consisted of one independent variable, one mediating variable, and one dependent variable. The analysis technique was used to test the effect between variables in this study is regression analysis with mediator variables. Regression analysis uses the basic concept of correlation but provides more information by showing a linear relationship between variables in the form of an equation [18]. SPSS 
22 Software with its Macro Process v3.5 has been chosen as the analysis tool for this study.

To process data with regression analysis, each variable must pass some tests such as validity test, reliability test, and the classic assumption test. The classic assumption test or the feasibility test consists of; multicollinearity test, normality test, heteroscedasticity test, and autocorrelation test. However, because this study uses a cross-sectional time horizon, there is no need to do an autocorrelation test, because the correlation test is carried out in research with a time horizon time series that is the time of data retrieval that is done many times in a certain period. After all, variables have passed the classical assumption test, then the data can be processed in regression analysis. Regression analysis is a mathematical model used to determine patterns of relationships between variables. In the regression analysis, there are values of $R^{2} \cdot R^{2}$ value is a unit to measure how much influence the independent variable has on the dependent variable. Because this study consists of independent, mediating, and dependent variables, the model used is regression analysis with mediator variables. A variable can be said to be a mediator variable if the variable affects the relationship between the predictor variable (independent) and the criterion (dependent) [19].

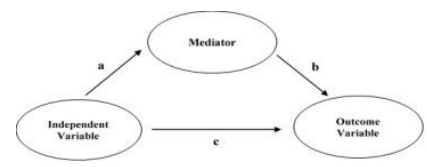

Figure 1 Diagram of Cause and Effect between Variables Sources: Baron and Kenny [19]

Baron and Kenny [19] introduce a path diagram as a model to illustrate the causal chain. The basic causal chain involved in mediation is illustrated in Figure 1. This model assumes a three-variable system such that two causal pathways go into the outcome variable: the direct impact of the independent variable (Line c) and the impact of the mediator (Line b). There is also a path from the independent variable to the mediator (Path a).

According to Baron and Kenny [19], to test a variable functioning as a mediator is when it meets the following criteria

1. The independent variable significantly influences the predicted mediator variable $\rightarrow$ Path a

2. Variation in mediator significantly influences the dependent variable $\rightarrow$ Path $b$

3. If the independent variable influence the dependent variables with relatively small effect after the intervening (mediating) variable, thus a perfect mediation happens.

\subsection{Data Demography}

\section{Results and Discussion}

Based on the results of the questionnaire obtained the following demographic data of respondents; $85 \%$ of the respondents were male. Regarding the educational background of $72.5 \%$ of S1 graduates, $20 \%$ of S2 graduates, and $7.5 \%$ of the remaining high school and junior high school graduates. For certification, 20\% of respondents have a Project Management Professional (PMP) certificate, $17.5 \%$ of respondents have a certificate other than Project Management, and $62.5 \%$ of respondents do not have a 
certificate. And regarding the length of time respondents worked in the company, as many as $30 \%$ of respondents had worked at PT XYZ for more than 9 years, $27.5 \%$ range 7-9 years, $17.5 \%$ range $4-6$ years, and $25 \%$ range 1-3 years. Detailed demographic information is shown in Table 1.

Table 1 Profile of the Respondents $(n=40)$

\begin{tabular}{|c|c|c|}
\hline Variable & Category & $\%$ \\
\hline \multirow{2}{*}{ Gender } & Male & 85 \\
\hline & Female & 15 \\
\hline \multirow[t]{3}{*}{ Educational Background } & Bachelor Degree & 72.5 \\
\hline & Master Degree & 20 \\
\hline & High school & 7.5 \\
\hline \multirow[t]{9}{*}{ Certification } & PMP & 20 \\
\hline & Application / System Specific Certification & 2.5 \\
\hline & PMF & 2.5 \\
\hline & Professional Scrum Master & 2.5 \\
\hline & PM BOK & 2.5 \\
\hline & MTCNA & 2.5 \\
\hline & CCNA, CCNP, CCSP, CCAI, MCP & 2.5 \\
\hline & LTE - Advance Key Technology & 2.5 \\
\hline & No Certification & 62.5 \\
\hline \multirow{4}{*}{ Working Experience } & $1-3$ years & 25 \\
\hline & $4-6$ years & 17.5 \\
\hline & $7-9$ years & 27.5 \\
\hline & $>9$ years & 30 \\
\hline
\end{tabular}

\section{Normality Test Result}

To reveal the distribution of the data, a normality test is done to test if data is normally distributed or free. In this study, the Kolmogorov-Smirnov (KS) test and the ShapiroWilk test using software SPSS 22. It is recommended to use Shapiro-Wilk normality test for this study as the sample sizes are less than 50 [20].

Table 2 Results of the Normality Test Shapiro-Wilk

\begin{tabular}{|l|c|c|c|c|c|c|}
\hline \multicolumn{7}{|c|}{ Tests of Normality } \\
\hline & \multicolumn{3}{|c|}{ Kolmogorov-Smirnova } & \multicolumn{3}{|c|}{ Shapiro-Wilk } \\
\cline { 2 - 8 } & Statistics & df & Sig. & Statistics & df & Sig. \\
\hline Knowledge_Skills & .72 & 40 & $.200 *$ & .899 & 40 & .960 \\
\hline Organizational_Driver & .089 & 40 & $.200 *$ & .970 & 40 & 363 \\
\hline Perceived_Success & .105 & 40 & $.200 *$ & .969 & 40 & .343 \\
\hline * This is a lower bound of true significance. \\
\hline a. Lilliefors Significance Correction \\
\hline
\end{tabular}

Based on the outputs in Table 2. The Sig. Knowledge \& Skills, Organizational Drivers, and Perceived Success amounted to 0.960, 0.363, and 0.343, which value is greater than the value $\alpha$ which is 0.05 . It can be concluded that the Knowledge \& 
Skills, Organizational Driver, and Perceived Success data are normally distributed, and can be continued to the validity test and reliability test.

\subsection{Results of the Validity Test}

A validity test is conducted to measure the validity of the questions or instruments of each variable on the questionnaire that has been distributed to respondents for research.

Table 3 Results of the Validity Test

\begin{tabular}{|c|c|c|c|c|}
\hline Item & R count & Sign & R table & Decision \\
\hline X1 & 0712 & $>$ & 0.31 & Valid \\
\hline X2 & 0871 & $>$ & 0.31 & Valid \\
\hline X3 & 0821 & $>$ & 0.31 & Valid \\
\hline X4 & 0.741 & $>$ & 0.31 & Valid \\
\hline X5 & 0.746 & $>$ & 0.31 & Valid \\
\hline X6 & 0.74 & $>$ & 0.31 & Valid \\
\hline X7 & 0.749 & $>$ & 0.31 & Valid \\
\hline X8 & 0.633 & $>$ & 0.31 & Valid \\
\hline X9 & 0.678 & $>$ & 0.31 & Valid \\
\hline X10 & 0.502 & $>$ & 0.31 & Valid \\
\hline M1 & 0722 & $>$ & 0.31 & Valid \\
\hline M2 & 0.803 & $>$ & 0.31 & Valid \\
\hline M3 & 0.86 & $>$ & 0.31 & Valid \\
\hline M4 & 0869 & $>$ & 0.31 & Valid \\
\hline M5 & 0.599 & $>$ & 0.31 & Valid \\
\hline Y1 & 0.809 & $>$ & 0.31 & Valid \\
\hline Y2 & 0845 & $>$ & 0.31 & Valid \\
\hline Y3 & 0869 & $>$ & 0.31 & Valid \\
\hline Y4 & 0.57 & $>$ & 0.31 & Valid \\
\hline
\end{tabular}

Based on the results of the output in Table 3. Obtained the value of $\mathrm{R}$ count all items greater than the statement $\mathrm{R}$ Table that is equal to 0.31 . Then it can be concluded that all items of the measurement instrument statement are declared valid and can proceed to the reliability test.

\subsection{Results of the Reliability Test}

Test Reliability is to measure how consistent an instrument is in measuring a concept. The reliability test shows the extent to which the instrument shall be free from error and furthermore it has to ensure a measurement consistently whenever the measurement is taken[21]. 
Table 4 Variable Knowledge \& Skills $(X)$ Reliability Test Result

\begin{tabular}{|c|c|c|c|}
\hline & \multicolumn{3}{|c|}{ Reliability Statistics } \\
\hline \multirow{2}{*}{$\mathbf{X}$} & Cronbach's Alpha & Cronbach's Alpha Based on Standardized Items & N of Items \\
\cline { 2 - 4 } & .897 & .898 & 10 \\
\hline
\end{tabular}

Table 5 Variable Organizational Driver (M) Results of the Reliability Test

\begin{tabular}{|c|c|c|c|}
\hline & \multicolumn{3}{|c|}{ Reliability Statistics } \\
\hline \multirow{2}{*}{$\mathbf{M}$} & Cronbach's Alpha & Cronbach's Alpha Based on Standardized Items & N of Items \\
\cline { 2 - 4 } & .835 & .831 & 5 \\
\hline
\end{tabular}

Table 6 Results of the Reliability Test - Perceived Success (Y)

\begin{tabular}{|c|c|c|c|}
\hline & \multicolumn{3}{|c|}{ Reliability Statistics } \\
\hline \multirow{2}{*}{$\mathbf{Y}$} & Cronbach's Alpha & Cronbach's Alpha Based on Standardized Items & N of Items \\
\cline { 2 - 4 } & .784 & .780 & 4 \\
\hline
\end{tabular}

Based on the outputs in Tables 4, 5, and 6, the value of $\mathrm{R}$ is obtained $\alpha$ Knowledge $\&$ Skills, Organizational Drivers, and Perceived Success variables are 0.897, 0.835, and 0.784 which are greater than 0.7 . Then it can be concluded that the score item of the Knowledge \& Skills variable, Organizational Driver, and Perceived Success are declared reliable.

After the Normality Test, Validity Test, and Reliability Test, proceed to the Classic Assumption Test as a prerequisite before conducting a Regression Test with Mediator Variables. The Classic Assumption Test consists of Multicollinearity Test, Normality Test, Heteroskedasticity Test, and Auto Correlation Test. However, the

The autocorrelation test was not performed because the data the researcher had were cross-section data.

\subsection{Classical Assumption Test}

The classical assumption test is a statistical requirement that must be met prior multiple linear regression analysis based on Ordinary Least Square (OLS). The purpose of this test is to ensure that the regression model is not biased or not BLUE (Best Linear Unlimited Estimator). Therefore, the classic assumption test is mandatory prior to the next analysis.

\section{Multicollinearity Test Result}

Multicollinearity test is used to test whether there is a high correlation between independent variables. If there is multicollinearity among the independent variables, then the relationship between the independent variable and the dependent variable is disturbed [22].

Referringto the result in Table 7, the Tolerance value of 0.465 is greater than 0.10 and the VIF value of 2.149 is smaller than 10. This shows that there is no multicollinearity between the independent variables. 
Table 7 Results of the Multicollinearity Test

\begin{tabular}{|l|c|c|c|c|c|c|c|}
\hline \multicolumn{7}{|c|}{ Coefficients } \\
\hline \multirow{2}{*}{ Model } & \multicolumn{2}{|c|}{$\begin{array}{c}\text { Unstandardized } \\
\text { Coefficients }\end{array}$} & $\begin{array}{c}\text { Standardized } \\
\text { Coefficients }\end{array}$ & \multirow{2}{*}{$\mathrm{t}$} & Sig. & \multicolumn{2}{c|}{$\begin{array}{c}\text { Collinearity } \\
\text { Statistics }\end{array}$} \\
\cline { 2 - 9 } & B & Std. Error & Beta & & $3,154.003$ & & \\
\hline Tolerance & VIF \\
\hline (Constant) & 7,545 & 2,393 & .501 & 2,563 & .015 & .465 & 2,149 \\
\hline Knowledge_Skills & .194 & .076 & .107 & .546 & 589 & .465 & 2,149 \\
\hline Organizational_Driver & .076 & .139 & & & & \\
\hline a. Dependent Variable: Perceived_Success
\end{tabular}

\section{Normality Test Result}

A good regression model is one where the distribution of residual data is normally distributed. So the normality test is not carried out on each variable but the residual value.

Table 8 Results of Normality Test

\begin{tabular}{|l|c|c|c|c|c|c|}
\hline \multicolumn{7}{|c|}{ Tests of Normality } \\
\hline & \multicolumn{3}{|l|}{ Kolmogorov-Smirnova } & \multicolumn{3}{|c|}{ Shapiro-Wilk } \\
\cline { 2 - 7 } & Statistics & df & Sig. & Statistics & df & Sig. \\
\hline Unstandardized Residual & .088 & 40 & $.200 *$ & .983 & 40 & .807 \\
\hline * This is a lower bound of true significance. \\
\hline
\end{tabular}

Based on the outputs in Table 8. the Sig. amounted to 0.807 greater than the value $\alpha$ which is 0.05 . Then it can be concluded that the residual data are normally distributed.

\section{Result of Heteroscedasticity Test}

The Heterokedasticity test is a test to find out whether there is an unequal variance of the variables in the regression model [22]. Many ways to see the presence or absence of heterokedasticity. However, researchers chose the Spearman Rank test.

Based on the outputs in Table 9. The Sig. Knowledge \& Skills and Organizational Drivers variables are 0.993 and 0.826 , respectively, which is greater than the value $\alpha$ which is 0.05 . Then it can be concluded that heteroscedasticity does not occur.

After the Classical Assumption Test is performed and the data meets the criteria, then a Regression Test can be performed with Mediator Variables. 
Table 9 Result of Heteroscedasticity Test

\begin{tabular}{|c|c|c|c|c|c|}
\hline \multicolumn{6}{|c|}{ Correlations } \\
\hline & & & $\begin{array}{c}\text { Knowledge_Skill } \\
\mathrm{s}\end{array}$ & $\begin{array}{c}\text { Organizational_Drive } \\
\text { r }\end{array}$ & $\begin{array}{c}\text { Unstandardize } \\
\text { d Residual }\end{array}$ \\
\hline \multirow{9}{*}{$\begin{array}{l}\text { Spearman' } \\
\text { s rho }\end{array}$} & \multirow{3}{*}{$\begin{array}{l}\text { Knowledge_ } \\
\text { Skills }\end{array}$} & \begin{tabular}{|l} 
Correlatio \\
$n$ \\
Coefficien \\
$\mathrm{t}$
\end{tabular} & 1,000 & $.716 * *$ & -001 \\
\hline & & \begin{tabular}{|l|} 
Sig. $(2-$ \\
tailed) \\
\end{tabular} & . & .000 & 993 \\
\hline & & $\mathrm{N}$ & 40 & 40 & 40 \\
\hline & \multirow{3}{*}{$\begin{array}{l}\text { Organizational_Drive } \\
\mathrm{r}\end{array}$} & $\begin{array}{l}\text { Correlatio } \\
n \\
\text { Coefficien } \\
t\end{array}$ & $.716 * *$ & 1,000 & -.036 \\
\hline & & \begin{tabular}{|l} 
Sig. $(2-$ \\
tailed) \\
\end{tabular} & .000 & . & .826 \\
\hline & & $\mathrm{N}$ & 40 & 40 & 40 \\
\hline & \multirow{3}{*}{$\begin{array}{l}\text { Unstandardized } \\
\text { Residual }\end{array}$} & \begin{tabular}{|l} 
Correlatio \\
$\mathrm{n}$ \\
Coefficien \\
$\mathrm{t}$ \\
\end{tabular} & -001 & -.036 & 1,000 \\
\hline & & \begin{tabular}{|l|} 
Sig. (2- \\
tailed) \\
\end{tabular} & 993 & .826 & . \\
\hline & & $\mathrm{N}$ & 40 & 40 & 40 \\
\hline
\end{tabular}

\subsection{Result of Regression Test with Mediator Variables}

Perfect mediation occurs when there are no effects of independent to dependent variables when mediator variables are included in the equation [19]. In the regression test with this mediator variable, researchers used SPSS macros created by [23] called PROCESS. The advantage of using this PROCESS macro is that the analysis only needs to be done once to determine the mediating effect. And for the assessment of mediation using criteria [19].

Based on the SPSS output, the coefficient a is $0.398(\beta a=0.731)$, the coefficient $b$ is $0.075(\beta b=0.106)$ and the c coefficient is $0.193(\beta c=0.501)$. Supported by ta value of 6,606 and significance of p-value a $(0,000)<0.05$, tb value of 0.545 and significance of p-value $b(0.588)>0.05$, and tc value of 2.562 and significance of p-value c (0.014) $<0.05$. Then, it can be concluded that the variable M (Organizational Drivers) does not affect $\mathrm{Y}$, while the variable $\mathrm{X}$ (Knowledge \& Skills) significantly influences the Y (Perceived Success) variable without the variable M.

\section{Coefficient of Determination}

Based on the output display in Table 10. Coefficient of determination $\left(R^{2}\right)$ for outcome variable Organizational Drivers is 0.534 so it can be concluded that $53.4 \%$ of the Knowledge \& Skills variables can explain the variation of the Organizational Drivers variable and the remaining $46.6 \%$ is explained by other variables. 
The Coefficient of determination $\left(R^{2}\right)$ for outcome variable Perceived Success is 0.534 so it can be concluded that $34.1 \%$ of the Knowledge \& Skills and Organizational Driversvariables can explain the variation of the Perceived Success variable and the remaining $65.9 \%$ is explained by other variables.

Table 10 Regression Test Results with Mediator Variables

\begin{tabular}{|c|c|c|c|c|c|c|c|}
\hline \multicolumn{2}{|c|}{ Outcome Variable } & & & & & & \\
\hline \multicolumn{2}{|c|}{ Organizational_Driver } & & & & & & \\
\hline Summary Model & & & & & & \\
\hline R & R-sq & MSE & F & df1 & df2 & $\mathrm{p}$ & \\
\hline Model & 0.5346 & 6.7805 & 43.6458 & 1 & 38 & 0 & \\
\hline \multicolumn{2}{|l|}{} & & & & & & \\
\hline Constant & coeff & $\mathrm{se}$ & $\mathrm{t}$ & $\mathrm{p}$ & LLCI & ULCI \\
\hline Knowledge_Skills & 0.4503 & 2.7031 & 1.6464 & 0.1079 & -1.0219 & 9,22226 \\
\hline \multicolumn{2}{|l|}{ Standardized Coefficients } & 0.0603 & 6.6065 & 0 & 0.2763 & 0.5205 \\
\hline \multicolumn{2}{|l|}{ Knowledge_Skills } & 0.7311 & & & & & \\
\hline
\end{tabular}

\begin{tabular}{|c|c|c|c|c|c|c|c|}
\hline \multicolumn{2}{|c|}{ Outcome Variable } & & & & & & \\
\hline Perceived_Success & & & & & & \\
\hline Summary Model & & & & & & \\
\hline $\mathrm{R}$ & $\mathrm{R}-\mathrm{sq}$ & $\mathrm{MSE}$ & $\mathrm{F}$ & $\mathrm{df} 1$ & $\mathrm{df} 2$ & $\mathrm{p}$ & \\
\hline 0.5839 & 0.341 & 4.9588 & 9.5711 & 2 & 37 & 0.0004 & \\
\hline Model & & & & & & \\
\hline \multicolumn{2}{|c|}{ constant } & coeff & $\mathrm{se}$ & $\mathrm{t}$ & $\mathrm{p}$ & LLCI & ULCI \\
\hline Knowledge_Skills & 0.19453 & 2.3927 & 3.1535 & 0.0032 & 2.6972 & 12.3344 \\
\hline Organizational_Drivers & 0.0757 & 0.1387 & 0.5456 & 0.5886 & -0.2054 & 0.3568 \\
\hline \multicolumn{2}{|c|}{ Standardized coefficients } & & & & & \\
\hline \multicolumn{2}{|l|}{} & coeff & & & & & \\
\hline Knowledge_Skills & 0.5013 & & & & & \\
\hline Organizational_Drivers & 0.1067 & & & & & \\
\hline
\end{tabular}

\section{Regression Equation}

Outcome Variable

Organizational Drivers

Perceived Success

$Y=\alpha+\beta c X$

$Y=\alpha+\beta c X+\beta b X M$

$Y=4.45+0.731 X$

$Y=7.545+0.501 X+0.106 X M$ 


\subsection{Analysis of Relationships between Variables}

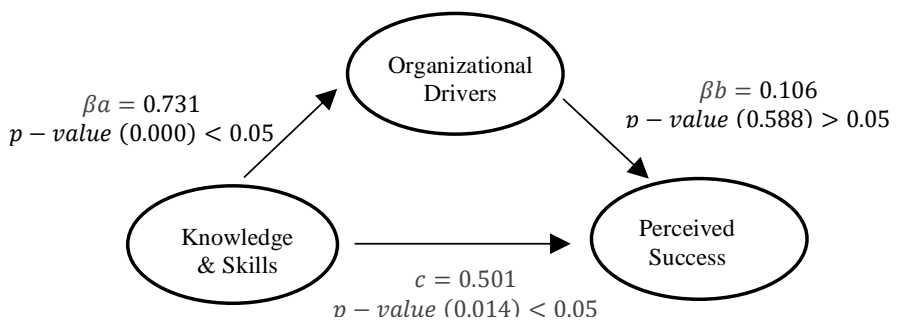

Figure 2 Results of Analysis of Regression Tests with Mediator Variables

Based on the results of regression tests with mediator variables, the results show that:

1. Pathway $a \rightarrow$ Knowledge \& Skills have a significant influence on Organizational Drivers.

2. Path $b \rightarrow$ Organizational Drivers have a significant effect on Perceived Success.

3. Lane $\mathrm{c} \rightarrow$ The relationship between Knowledge \& Skills with Perceived Success becomes insignificant when the Organizational Drivers variable is included because Organizational Drivers do not affect Perceived Success.

Because paths a and $c$ are significant but pathway $b$ is not significant, then it refers to criteria Baron and Kenny [19] it can be concluded that there is no mediating role between the relationship of independent variables (Knowledge \& Skills) and the dependent variable (Perceived Success).

Table 11 Value of Inter-Variable Effects

\begin{tabular}{|c|c|c|c|c|c|c|c|}
\hline \multicolumn{2}{|l|}{ Total effect of X on Y } & & & & & & \\
\hline Effect & se & $\mathrm{t}$ & $\mathrm{p}$ & LLCI & ULCI & c_ps & c_cs \\
\hline 0.2239 & 0.0511 & 4.3817 & 0.0001 & 0.1204 & 0.3273 & 0.0838 & 0.5794 \\
\hline Direct effect of X on Y & & & & & & \\
\hline Effect & se & $\mathrm{t}$ & $\mathrm{p}$ & LLCI & ULCI & c'_ps & c'_cs \\
\hline 0.1937 & 0.0756 & 2,5626 & 0.0146 & 0.0405 & 0.3469 & 0.0725 & 0.5013 \\
\hline Indirect effect (s) of X on Y: & & & & & \\
\hline
\end{tabular}

Besides based on Baron and Kenny [19] criteria to convey that there is a mediating role or not, it can also be seen by a $95 \%$ confidence interval (CI) based on the bootstrap results in 5000 samples. If the BootLLCI and BootULCI ranges do not include zero (0), then a significant estimate can be concluded and a mediating effect occurs [23].

Based on the results of the output in Table 11. obtained the confidence interval value (Confidence Interval / CI) from the bootstrap results as follows:

\section{BootLLCI (Lower Level CI) $=-0.0754$ \\ BootULCI (Upper Level CI) $=0.1434$}

From the results of the above bootstrap values, the Boot LLCI and BootULCI ranges cover a zero value (0), so it can be concluded that there is no mediating effect. Because zero is not included in the $95 \%$ confidence interval, there is a significant direct effect 
between Knowledge \& Skills on Perceived Success without going through Organizational Drivers.

\subsection{Research Implications}

Based on the results of the research hypothesis test and the data presented above, the resulting managerial discussion and implications are as follows

Effect of Knowledge \& Skills on Organizational Drivers Based on the results of the regression test, the significance value between Knowledge \& Skills and Organizational Driver is 0.000 , which results are smaller than the significance level of $0.05(0.000<0.05)$. It can be concluded that there is a positive and significant effect between Knowledge \& Skills and Organizational Drivers. If PT XYZ has resources with good knowledge and skills, this will increase the company's drive to develop Agile Project Management methods in the company.

\section{The Effect of Organizational Drivers on Perceived Success}

Based on the regression test results obtained a significance value between Organizational Driver and Perceived Success of 0.588 which results are greater than the significance level of $0.05(0.588<0.05)$. Then it can be concluded that there is no significant effect between Organizational Driver and Perceived Success. In addition to the quality of its resources, company encouragement can also determine the success of implementing Agile Project Management in the company. However, because of the encouragement of PT XYZ in developing the Agile Project Management method in the company, it was not very supportive, so the success rate was also small.

\section{Effect of Knowledge \& Skills on Perceived Success}

Based on the regression test results obtained a significance value between Knowledge $\&$ Skills and Perceived Success of 0,000 which results are smaller than the significance level of $0.05(0.014<0.05)$. Then it can be concluded that there is a positive and significant effect between Knowledge \& Skills and Perceived Success. The better the knowledge and skills of PT XYZ employees, the higher the success rate of the project team in implementing Agile Project Management in the company.

\section{The Effect of Knowledge \& Skills on Perceived Success Mediated by Organizational Drivers}

Based on the results of regression tests with mediator variables, the significance value between Knowledge \& Skills and Perceived Success is 0.000 , which results are smaller than the significance level of $0.05(0.014<0.05)$, meaning that there is a positive and significant effect between Knowledge \& Skills and Perceived Success. However, after entering the Organizational Driver variable as a mediator between Knowledge \& Skills and Perceived Success the results are not significant. Based on the results of the regression test, the significance value between Knowledge \& Skills and Organizational Driver is $(0.000<0.05)$ and the significance value between Organizational Driver and Perceived Success is 0.588 which results are greater than the significance level of $0.05(0.588>0.05)$. It can be concluded that the Organizational Drivers variable does not mediate the relationship between the Knowledge \& Skills variable and the Perceived Success. The better the knowledge and 
skills of PT XYZ employees, the higher the level of success in implementing Agile Project Management in the company. But from the results of this study, the encouragement of PT XYZ in developing the Agile method in the company was less supportive. Because the encouragement from the company itself is not very supportive, the high level of knowledge and skills from its resources can be the success of the implementation of Agile Project Management in the company.

\section{Conclusion}

The results of the analysis prove that the Knowledge \& Skills variable has a significant effect on Perceived Success. This is supported by the results of regression tests with mediator variables, obtained $\mathrm{p}$-value $(0.014)<0.05$ which means that there is a significant influence between the Knowledge \& Skills variable on Perceived Success. Then, related to the formulation of the second problem in this study, on how organizational drivers mediate the relationship between knowledge \& skills and perceived success in the implementation of Agile Project Management at PT XYZ, the results of the analysis prove that Organizational Drivers do not support mediating the relationship between Knowledge \& Skills and Perceived Success. This is supported by the results of regression tests with mediator variables, path c produces a p-value of $(0.014)<0.05$ which means that there is a significant influence between the Knowledge $\&$ Skills variable on Perceived Success. However, after entering the Organizational Driver variable, the relationship between Knowledge \& Skills with Perceived Success is no longer significant. Supported by the results of regression tests with mediator variables, line a produces a p-value of $(0,000)<0.05$, which means there is a significant influence between the Knowledge \& Skills variable on Organizational Drivers, and path $b$ produces a p-value of (0.588)> 0.05 which meaning that there is no significant effect between Organizational Driver variables on Perceived Success. Then, it can be concluded that the variable Organizational Drivers do not support mediating the relationship between Knowledge \& Skills with Perceived Success in the implementation of Agile Project Management at PT XYZ.

To be able to strengthen Perceived Success in PT XYZ, employees need to be frequently given training related to Agile Project Management, to create awareness from team members regarding agile manifesto in agile project management. In addition, regular meetings between team members and project managers also need to be held so that the implementation of Agile in the current project can run smoothly. In the regular meeting, all teams must focus on knowledge sharing focusing on how the Agile method works on the project, as well as implementing an agile manifesto. In addition to the need for regular agile training for team members, the head of the project must also have a series of strict regulations per the agile manifesto that is easily understood by all team members so that they can work on the project well and smoothly to have a higher effect on the perceived success of a project.

\section{References}

1. suara.com, "Kemnaker Minta Pegawai Adaptasi dengan Perkembangan Teknologi Informasi," 16 Juli 2019. [Online]. Available: https://www.suara.com/tekno/2019/07/16/084701/kemnaker-minta-pegawaiadaptasi-dengan-perkembangan-teknologi-informasi. 
2. E. Conforto, F. Salum, D. Amaral, S. L. da Silva and L. F. de Almeida, "Can Agile Project Management Be Adopted by Industries Other than Software Development?," Project Management Journal, pp. 21-34, 2014.

3. Z. A. Masood and S. Farooq, "The Benefits and Key Challenges of Agile Project Management under Recent Research Opportunities," International Research Journal of Management Sciences, pp. 20-28, 2017.

4. J. Noutilla, K. Aaltonen and J. Kujala, "Challenges of adopting agile methods in a public," International Journal of Information Systems and Project Management, pp. 65-85, 2016.

5. T. Reainthong, "Agile Manifesto Values and Principles," 16 Feb 2020. [Online]. Available: https://www.projectmanagement.com/wikis/295395/Agile-ManifestoValues-and-Principles.

6. T. Lappi, T. Karvonen, L. E. Lwakatare, K. Aaltonen and P. Kuvaja, "Toward an Improved Understanding of Agile Project Governance: A Systematic Literature Review," Project Management Journal, pp. 39-63, 2018.

7. C. Prange and J. C. Pinho, "How personal and organizational drivers impact on SME international performance: The mediating role of organizational innovation," International Business Review, pp. 1-10, 2017.

8. T. Chiyangwa and E. Mnkandla, "Agile methodology perceived success and its use: The moderating effect of perceived compatibility," South African Computer Journal, pp. 1-16, 2018.

9. M. L. Drury-Grogan, "Performance on agile teams: Relating iteration objectives and critical decisions to project management success factors," Information and Software Technology, pp. 506-515, 2014.

10. P. Williams, N. Ashill, E. Naumann and E. Jackson, "Relationship quality and satisfaction: Customer-perceived success factors for on-time projects," International Journal of Project Management, pp. 1-15, 2015.

11. P. Serrador and P. Jeffrey K., "Does Agile work? - A quantitative analysis of agile project success," International Journal of Project Management, pp. 10401051, 2015.

12. P. D. H. M. Rahardjo, "Case Study in Qualitative Research : Concepts and Procedures," Universities Islam Negeri Maulana Malik Ibrahim, Malang, 2017.

13. H. Nassaji, "Qualitative and descriptive research: Data type versus data analysis," Language Teaching Research, pp. 129-132, 2016.

14. Joshi, S. Kale, S. Chandel and D. K. Pal, "Likert Scale: Explored and Explained," British Journal of Applied Science \& Technology, pp. 396-403, 2015.

15. J. T. Croasmun and L. Ostrom, "Using Likert-Type Scales in the Social Sciences," Journal of Adult Education, pp. 19-22, 2011.

16. Etikan, S. A. Musa and R. S. Alkassim, "Comparison of Convenience Sampling and Purposive Sampling," American Journal of Theoretical and Applied Statistics, pp. 1-4, 2016.

17. Sugiyono, Mix Methods Research, Bandung: Alfabeta, 2015.

18. D. Lind, W. Marchal and S. Wathen, Statistical Techniques in Business and Economics 17th Edition, -: McGraw-Hill, 2018.

19. R. M. Baron and D. A. Kenny, "The mediator-moderator variable distinction in social psychological research: Conceptual, strategic, and statistical 
considerations," Journal of Personality and Social Psychology, pp. 1173-1182, 1986.

20. Ghasemi and S. Zahediasl, "Normality Tests for Statistical Analysis: A Guide for Non-Statisticians," International Journal of Endocrinology \& Metabolism, pp. 486-489, 2012.

21. U. Sekaran and R. Bougie, Research Methods for Business, Chichester: Wiley, 2016.

22. Ghozali, Multivariate Analysis Application with the IBM SPSS Program, Semarang: Badan Penerbit Universities Diponegoro, 2013.

23. F. Hayes, Introduction to mediation, moderation, and conditional process analysis, New York: Guilford, 2013.

\section{About Our Authors}

Mohammad Hamsal is an Associate Professor of Binus Business School (BBS) of Bina Nusantara University. He was graduated from Bandung Institute of Technology before pursuing his Master of Quality Management and Master of Systems Engineering in from Royal Melbourne Institute of Technology and his MBA degree from Victoria University in Melbourne, Australia. He earned his $\mathrm{PhD}$ from the University of Indonesia in Strategic Management. He has been teaching in BBS Doctorate Program since 2004. His research domain are Organizational Transformation, Business Model Innovation, Strategic Agility, and Supply Chain Management.

Mohammad Ichsan is an Assistant Professor in Binus Business School of Bina Nusantara University (AACSB accredited). He has pursued his DiplomIngenieur in Electrical Engineering from Hochschule Darmstadt, Germany prior to get his master's degree in project management from the University of Indonesia. Dr. Ichsan has continued his study and received his doctoral degree in Strategic Management. His teaching area is project management and operations management, meanwhile his research domain is project portfolio management, project management office practices and project risk management.

Annisa Rizky Utomo, Aulia Ayu Fahira, Rima Emeralda Wetik are students from Binus Business School Undergraduate Program, Management Program. They are completing their bachelor's degree in Management in area of Quality Management. Their thesis is supervised by Dr. Mohammad Ichsan. 